\title{
Zachowania przedsiębiorstw lokalnych a ekspansja inwestorów zagranicznych w Polsce
}

https://doi.org/10.33141/po.2005.09.04

Przegląd Organizacji, Nr 9 (788), 2005, ss. 20-23

www.przegladorganizacji.pl

Towarzystwo Naukowe Organizacji i Kierownictwa (TNOiK)

Marian Gorynia, Małgorzata Bartosik-Purgat, Barbara Jankowska, Radosław Owczarzak

\section{Uzasadnienie i istota badania}

W ciągu minionych piętnastu lat równolegle z transformacją gospodarki polskiej zachodził proces jej integrowania się $\mathrm{z}$ międzynarodowym otoczeniem gospodarczym. O ile transformacja w gospodarkę rynkową jest procesem o ograniczonym horyzoncie czasowym, o tyle integracja z gospodarką międzynarodową jest procesem, który nigdy nie powinien się zakończyć. Stąd zrozumiała staje się konieczność przesunięcia akcentów badawczych z problematyki transformacji na problematykę internacjonalizacji i globalizacji. Internacjonalizacja i globalizacja to podstawowe przejawy postępującego włączania się gospodarki polskiej do gospodarki światowej.

W tradycji teoretycznej właściwej szeroko rozumianym naukom ekonomicznym internacjonalizację i globalizację można odnosić zarówno do poziomu całych gospodarek narodowych, jak i do ich podstawowych elementów, czyli przedsiębiorstw. W niniejszym artykule, podobnie jak i w całym wspomnianym tutaj projekcie badawczym, uwaga została skupiona na poziomie przedsiębiorstwa. Można wskazać trzy argumenty przemawiające za przyjęciem takiej perspektywy badawczej.

Pierwszy argument uzasadniający to posunięcie wynikał z faktu, że przedsiębiorstwa są podstawowymi aktorami $\mathrm{w}$ procesach konkurencji międzynarodowej - to firmy zdobywają pozycje konkurencyjne, budują odpowiednie do warunków potencjały konkurencyjne, a także stosują określone strategie konkurencyjne posługujacc się stosownymi instrumentami konkurowania. Główną areną międzynarodowej walki konkurencyjnej są poszczególne rynki branżowe, na których rywalizują przedsiębiorstwa z różnych krajów.

Drugi argument nawiązywał do aktualnego stanu badań i wiedzy w zakresie międzynarodowych zachowań przedsiębiorstw. Przyspieszenie procesów postępu technicznego, możliwości stwarzane przez rozwój technologii informacyjnych, „kalifornizacja” potrzeb, chęć osiągnięcia korzyści skali itp. czynniki powodują, że warunki rynkowe wymuszają na firmach dokony- wanie ekspansji zagranicznej ${ }^{1}$. Ekspansja ta przybiera różne formy - od eksportu poprzez różne odmiany kooperacji kapitałowej i niekapitałowej, do podejmowania samodzielnej działalności gospodarczej na rynkach zagranicznych. Zagadnienia te są dość dobrze zbadane i opisane w różnych teoriach internacjonalizacji firmy. Oczywiście cały czas występuje uzasadnienie kontynuacji i aktualizacji badań w tej dziedzinie. Ważną cechą współczesnej konkurencji międzynarodowej jest szybki wzrost znaczenia zagranicznych inwestycji bezpośrednich. Zjawisko to na poziomie mikroekonomicznym analizowane jest przede wszystkim w licznych teoriach zajmujących się zachowaniami przedsiębiorstw międzynarodowych, wielonarodowych, ponadnarodowych itp. W przypadku gospodarki polskiej, która jest nie tyle stroną dokonującą zagranicznych inwestycji bezpośrednich, ile przede wszystkim biorca tych inwestycji, podstawowe znaczenie ma dobre rozpoznanie teoretyczne rzeczywistości gospodarczej - strategii firm polskich wobec inwestorów zagranicznych i wypracowanie zaleceń pod adresem strategii przedsiębiorstw i polityki gospodarczej. Z rozeznania zespołu badawczego wynika, że stan wiedzy w tej dziedzinie nie jest szczególnie rozwinięty. Istniejące modele teoretyczne oraz prowadzone badania empiryczne odnoszą się przede wszystkim do inwestorów zagranicznych wchodzących na rynek polski. Zachowania inwestorów zagranicznych są analizowane przez pryzmat motywów ekspansji na rynek polski (poszukiwanie rynku, poszukiwanie obniżki kosztów, poszukiwanie efektywności, poszukiwanie źródeł zaopatrzenia), pod kątem liczby etapów klasycznego procesu internacjonalizacji, przez które przeszła firma wchodząca na dany rynek, a także z punktu widzenia trudności napotykanych w Polsce. Mniej liczne są analizy nawiązujące do podejścia sieciowego (network approach) oraz do teorii kosztów transakcyjnych zastosowanej do wyjaśnienia ekspansji zagranicznej przedsiębiorstw. Nie ma natomiast prawie wcale opracowań przedstawiających od strony teoretycznej i badających praktyczne aspekty strategii firm polskich, które zetknęły się z inwestorami zagranicznymi na rynku polskim. 
Wreszcie trzeci argument wynikał z profilu zainteresowań naukowych kierownika projektu i członków zespołu badawczego. Ich dotychczasowy dorobek koncentruje się wokół zachowań przedsiębiorstw w gospodarce rynkowej, w tym w gospodarce kraju przechodzącego transformację oraz strategii przedsiębiorstw w biznesie międzynarodowym.

Podsumowując powyższe uwagi należy więc podkreślić, że w większości dotychczas zrealizowanych badań uwaga była zogniskowana najczęściej na zachowaniach firm prowadzacych ekspansję w formie zagranicznych inwestycji bezpośrednich. Zdecydowanie mniej uwagi poświęcano natomiast strategiom firm kraju goszczącego zagraniczne inwestycje bezpośrednie, przyjmowanym w obliczu ekspansji inwestorów zagranicznych.

Ideę zrealizowanego projektu badawczego ${ }^{2)}$ można streścić w następujący sposób. Jeśli rozważymy gospodarkę jakiegoś hipotetycznego kraju X, to łatwo zauważyć, że w warunkach gospodarki otwartej, prowadzącej w różnych formach współpracę z zagranicą, dochodzi do konfrontacji strategii co najmniej dwóch kategorii firm: • firm krajowych, • firm zagranicznych.

Dla firm krajowych rynek lokalny jest zazwyczaj rynkiem bazowym, podstawowym, który - historycznie rzecz biorąc - był rynkiem pierwotnym prowadzonej działalności. Firmy te, motywowane różnymi pobudkami, moga dokonywać ekspansji na rynki zagraniczne, realizując własne strategie internacjonalizacji.

Dla firm zagranicznych dany rynek jest zazwyczaj rynkiem wtórnej (w odniesieniu do ich rynku krajowego) ekspansji, który jest „zagospodarowywany” w drugiej kolejności. Firmy te realizują określone strategie internacjonalizacji, wchodzac na dany rynek i następnie prowadząc na nim rozwój działalności na różne sposoby. Jedną z realizowanych strategii może być dokonywanie zagranicznych inwestycji bezpośrednich.

Punkt ciężkości zainteresowań projektu badawczego stanowiły więc procesy konfrontacji strategii firm lokalnych kraju X (Polski) i firm zagranicznych wchodzących na ten rynek w różnych formach, ze zwróceniem szczególnej uwagi na zagraniczne inwestycje bezpośrednie. Akcent położony był na strategie firm lokalnych. Główne zadanie badawcze sprowadzało się do udzielenia odpowiedzi na trzy pytania:

- jakie strategie w obliczu ekspansji firm zagranicznych firmy lokalne mogą realizować,

- jakie strategie realizuja,

- jakie strategie powinny realizować?

\section{Synteza uzyskanych wyników}

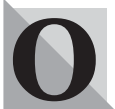

dpowiedzi na pierwsze z postawionych pytań podporządkowano szeroko zakrojone badania literaturowe, których efekty tutaj pominiemy.

Odpowiedzi na drugie z powyższych pytań służyły badania adresowane do firm polskich (lokalnych), które stanęły wobec wyzwań związanych z przyjęciem, a więc wyborem i realizacją określonych zachowań w stosunku do strategii ekspansji firm zagranicznych na rynku polskim. Lista najważniejszych pytań badawczych, które analizowano w badaniu empirycznym przedstawiała się następująco:

- jakie typy zachowań firm polskich (kraju goszczącego) wobec inwestorów zagranicznych przeważają,

- jakie są efekty rywalizacji (kooperacji),

- jaka jest (była) wyjściowa konkurencyjność firm krajowych wobec foreign invadors,

- jakie zmiany w konkurencyjności firm kraju goszczącego spowodowane są przez wejścia inwestorów zagranicznych,

- jakie sa mikro-, mezo- i makroekonomiczne konsekwencje ekspansji foreign invadors?

Badanie empiryczne przeprowadzone w 2004 roku, obejmujące 77 firm $^{3)}$ kraju goszczącego, czyli Polski, należących do trzech branż (spożywcza, budowlana, motoryzacyjna), dało podstawę do sformułowania zestawu wniosków dotyczących badanych firm i ich otoczenia. Konkluzje te są następujące.

- Badane firmy są zgodne w kwestii nasilania się procesu globalizacji, nie postrzegają go jako abstrakcyjnej tendencji, lecz dostrzegają wyraźnie przejawy ich rosnacego w nim udziału; na uwagę zasługuje przede wszystkim upodabnianie się rynków oraz wzrost presji konkurencyjnej.

- Badane firmy uważają, że najbardziej istotnym z ich punktu widzenia, dominujacym przejawem obecności konkurentów zagranicznych na rynku polskim są zagraniczne inwestycje bezpośrednie w formie filii i oddziałów oraz przejęć firm lokalnych - oznacza to, że penetracja eksportowa rynku polskiego przestała być $\mathrm{w}$ badanych branżach główną formą obecności rywali zagranicznych na rynku polskim (wyjątkiem jest tutaj branża motoryzacyjna).

- Badane firmy postrzegają, że podstawowym motywem zaangażowania się inwestorów zagranicznych na rynku polskim był motyw zdobycia rynku (w przypadku branży motoryzacyjnej uznano, że równie istotnym motywem był motyw zdobycia dostępu do tańszych zasobów).

- W badanych latach (pięć lat: 2000-2004) nastąpił w tendencji wzrost liczby konkurentów, a jednocześnie mieliśmy do czynienia ze wzrostem ich potencjału konkurencyjnego; można więc mówić o występowaniu zjawiska wzrostu natężenia konkurencji.

- Bariery administracyjne nie są dominującymi barierami wejścia do badanych branż, ważniejsze są bariery o podłożu ekonomicznym, takie jak: cena, zróżnicowanie produktów itp.

- Charakter stosunków panujących pomiędzy rywalami w branży jest dość skomplikowany i zróżnicowany; nie są to tylko i wyłącznie relacje konkurencyjne; na przykład branża motoryzacyjna wyróżnia się ponadprzeciętną skłonnością do zawiązywania więzi kooperacyjnych, czego nie obserwuje się na szerszą skalę w branży spożywczej.

- Dominujacym typem konkurencji w branży budowlanej i motoryzacyjnej pozostaje konkurencja cenowa, natomiast w branży spożywczej nastąpił zwrot w kierunku wzrostu znaczenia konkurencji poprzez zróżnicowanie.

- W nastawieniu przedsiębiorstw polskich do wejść firm zagranicznych na rynek polski początkowo dominowały postawy rywalizacyjne, które z czasem czę- 
ściowo przekształciły się w strategie kooperacyjne oraz w strategie poszukiwania niszy.

- Większość badanych firm polskich podała, że podstawowym motywem dążenia do utrzymania przez nie niezależności od kapitału zagranicznego była pozycja zdobyta na rynku polskim i obawa przed jej erozją (utratą tożsamości) poprzez wejście w bliższe związki z kapitałem zagranicznym.

- Negatywnie ocenianymi aspektami obecności firm z kapitałem zagranicznym na rynku polskim są: wpływ na poziom bezrobocia oraz ograniczanie możliwości ekspansji (dostępu do rynku) firm polskich, natomiast pozytywny wpływ wejścia i działalności firm zagranicznych na rynku polskim dostrzegany jest w obszarach: dostępu do nowych technologii, innowacyjności produktów, jakości i wydajności polskich firm oraz kwalifikacji kadry kierowniczej.

- Podmioty z udziałem kapitału zagranicznego nie są postrzegane jako szczególnie wyróżniający się (zarówno in plus, jak i in minus) uczestnicy branżowych grup nacisku; w tym przypadku można raczej mówić o znaczących umiejętnościach kapitału zagranicznego w zakresie dostosowania się do warunków panujących w Polsce, aniżeli o pozytywnym wpływie cywilizacyjnym i kulturowym rywali zagranicznych na złagodzenie niezbyt pozytywnych lokalnych obyczajów $\mathrm{w}$ tej dziedzinie.

- W zakresie działań samorządu gospodarczego uwagę zwracają bardzo duże oczekiwania po stronie przedsiębiorstw pod jego adresem, którym jednakże towarzyszy niska ocena realizacji funkcji spełnianych przez samorząd; jest to sytuacja niepokojąca, gdyż nie zmienia się ona znacząco praktycznie od początku transformacji w Polsce.

- Badane firmy nie oczekują interwencji państwa w pojedynczych przedsiębiorstwach oraz selektywnej polityki przemysłowej adresowanej do wybranych branż, jednocześnie jednak nie są zadowolone ze sposobu wykorzystania większości stosowanych instrumentów polskiej polityki gospodarczej.

- W zakresie pozycji konkurencyjnej (mierzonej udziałem w rynku i rentownością) w stosunku do obecnych na polskim rynku rywali zagranicznych, badane firmy oceniają się niżej od przeciętnego rywala, ale jednocześnie demonstruja ofensywną postawę przewidując poprawę tej pozycji w średnim okresie (3 lata).

- W odniesieniu do potencjału konkurencyjnego najsłabiej w porównaniu do przeciętnego rywala zagranicznego obecnego na polskim rynku badane przedsiębiorstwa oceniają poziom swoich nakładów na badania i rozwój, finansowanie działalności bieżącej ze środków obcych, wielkość firmy oraz możliwości finansowania działalności bieżącej firmy ze środków własnych; najsilniejsze elementy potencjału badanych firm w ich opinii to dopasowanie produktów/usług do gustów polskich konsumentów oraz jakość; w ocenie badanych podmiotów, za trzy lata niemal wszystkie wyróżnione elementy potencjału konkurencyjnego ulegna nieznacznej poprawie.

- Jeśli chodzi o instrumenty konkurowania (porównanie z konkurentami zagranicznymi obecnymi na rynku polskim), to wśród najniżej ocenianych przez ogół badanych firm znajdują się: reklama i promocja sprzedaży, częstotliwość wprowadzania nowych produktów oraz nowoczesność produktów/usług; ogół badanych firm wśród wykorzystywanych instrumentów konkurowania relatywnie najlepiej postrzega: cenę, warunki dostaw oraz terminowość dostaw; badane firmy wydają się świadome znaczenia starań o wzmocnienie instrumentów konkurowania i przewiduja, że za trzy lata poprawie, co najmniej do poziomu konkurentów zagranicznych obecnych na polskim rynku, ulegną wszystkie instrumenty wskazane jako najsłabsze.

- Bardzo istotnym elementem strategii badanych firm są powiązania kooperacyjne zarówno z partnerami krajowymi, jak i z partnerami pochodzenia zagranicznego; w przyszłości przewiduje się wzrost znaczenia powiązań kooperacyjnych, jednakże ze znaczącym zróżnicowaniem znaczenia w przekroju poszczególnych branż.

- Badane firmy odznaczają się dużym zakresem aktywności w zakresie realizacji strategii przystosowawczych do nowych warunków, w których przyszło im lub przyjdzie działać; co do większości wyróżnionych w kwestionariuszu badawczym działań przystosowawczych stwierdzono, że działania te są już prowadzone lub że planuje się ich podjęcie.

\section{Implikacje dla firm, samorządu gospodarczego i polityki gospodarczej}

W odpowiedzi na trzecie zadane na wstępie pytanie opracowano zestaw rekomendacji dla strategii firm oraz, dodatkowo, zaleceń adresowanych do samorządu gospodarczego i polityki gospodarczej.

Przygotowane zalecenia pod adresem praktyki gospodarczej opierają się na dwóch podstawach. Pierwsza, szersza i nie wiążąca się bezpośrednio z przeprowadzonymi przez zespół badaniami empirycznymi, stanowi nawiązanie do tych teorii i doktryn ekonomicznych, które zdają się zdobywać we współczesnej myśli ekonomicznej coraz większą popularność, a co za tym idzie - stają się coraz częściej teoretycznymi uzasadnieniami prowadzonej polityki ekonomicznej lub stanowią podstawę strategii realizowanych przez firmy. Drugim źródłem inspiracji do sformułowania zawartych tutaj poglądów są wyniki badań empirycznych przeprowadzonych w ramach relacjonowanego projektu badawczego, a także inne obserwacje praktyczne, prezentowane w prasie fachowej.

Jeśli chodzi o aspekt mikroekonomiczny prowadzonych rozważań, to nawiązuje się do takich podstawowych koncepcji i teorii przedsiębiorstwa, jak:

- zasobowa teoria przedsiębiorstwa (będąca jedną ze szkół w ramach nurtu zarządzania strategicznego),

- koncepcja przedsiębiorstwa jako organizacji uczącej się,

- koncepcja firmy w ramach ekonomii ewolucyjnej,

- koncepcje firmy w ramach nowej ekonomii instytucjonalnej (teoria kosztów transakcyjnych, teoria agencji, teoria praw własności),

- koncepcje strategii konkurencyjnej.

Jeśli chodzi natomiast o źródła inspiracji do rozważań prowadzonych w odniesieniu do polityki gospodarczej realizowanej przez państwo, to należy wska- 
zać na doktrynę liberalną w wersji instytucjonalnej, doktryny wspierania rynku oraz koncepcję liberalnoinstytucjonalnej polityki przemysłowej ${ }^{4)}$.

Tytułem podsumowania zaleceń strategicznych adresowanych do firm lokalnych w obliczu ekspansji inwestorów zagranicznych na rynku polskim sformułowano kilka uwag o charakterze bardziej ogólnym.

- Nie ma jednej najlepszej strategii, nie ma prostej recepty na wybór optymalnej strategii firm krajowych wobec ekspansji inwestorów zagranicznych. Potwierdzają się więc w tym przypadku zalecenia formułowane w ramach podejścia sytuacyjnego, zgodnie z którym najlepsza strategia w danych warunkach zależy od wypadkowej (splotu) czynników sytuacyjnych. Przenoszenie jednych rozwiązań z danego kontekstu sytuacyjnego do innego kontekstu jest obciążone wysokim ryzykiem niepowodzenia.

- Badanie potwierdziło, że bardzo zróżnicowane strategie moga prowadzić do osiąnięcia sukcesu. W jednych przypadkach powiodło się firmom, które imitowały zachowania rywali zagranicznych, w innych przewagę uzyskiwały firmy, które zdecydowały się na otwartą walkę konkurencyjną, w jeszcze innych powodzenie było udziałem firm, które zdecydowały się na realizację strategii niecki.

- Cechą wspólną realizowanych strategii, które doprowadziły do sukcesu, było przywiązywanie dużej wagi do ilości, jakości i struktury zasobów. Można więc mówić o ogólnym zasobowym uwarunkowaniu dobrej strategii. Bez odpowiednich co do ilości i jakości zasobów trudno jest realizować strategie sukcesu.

- Można też zauważyć, że w niektórych przypadkach bardzo dobre rezultaty przyniosła postawa firm cechująca się dużą „odwagą strategiczną”. Można tak określić sytuacje, w których a priori wydawałoby się, że podejmowanie walki konkurencyjnej z silnymi rywalami zagranicznymi nie ma sensu. Niektóre firmy zdecydowały się jednak na podjęcie wyzwania, jakim była rywalizacja z międzynarodowymi gigantami, i próba sił zakończyła się sukcesem, przynajmniej w średniookresowej perspektywie.

- Z opisanych powyżej okoliczności można wyciągnąć wniosek o bardziej optymistycznej wymowie - firmy polskie w konfrontacji z rywalami (inwestorami) zagranicznymi na rynku polskim nie stały ex definitione na straconej pozycji. W odniesieniu do przyszłości należy więc zalecać podejmowanie odważniejszych strategii, budowanych na bazie świadomie i skrupulatnie tworzonych przewag konkurencyjnych. Przesłanki do uzyskiwania przewagi kosztowo-cenowej przez firmy zlokalizowane w Polsce będą utrzymywać się jeszcze przez wiele lat, co powinno być atutem nie bez znaczenia. Towarzyszyć temu powinna kontynuacja wysiłków nad poprawą ogólnego poziomu zarządzania, w tym zarządzania strategicznego. Jednocześnie należy zauważyć, że dostęp do niezłych zasobów kadrowych oraz poprawa warunków infrastrukturalnych stwarzać powinny solidną bazę do rozwijania strategii sukcesu.

- Nasuwa się też postulat, aby szerzej stosować strategię różnicowania; czasami inwestycja w rynek i w markę dużo kosztuje, ale też daje dużo lepsze rezultaty.

Na zakończenie należy z całym naciskiem podkreślić, że często spotykane postrzeganie relacji między firmami lokalnymi a inwestorami zagranicznymi wyłącznie czy przede wszystkim w kategoriach walki (gra o sumie zerowej, w której ktoś traci, a ktoś inny korzysta) jest jednostronne i nieuzasadnione, a ponadto nie wytrzymuje próby konfrontacji z rzeczywistością. Jak wykazały przeprowadzone badania, relacje te sa o wiele bardziej różnorodne i rodzą rozmaite konsekwencje. Firmy zagraniczne wchodzace jako inwestorzy na rynek polski staja się firmami de facto polskimi - zatrudniają polskich pracowników, płacą na miejscu podatki, staja się konkurentami, kooperantami, dostawcami i odbiorcami lokalnych przedsiębiorstw itp. Firmy zagraniczne, jeśli tylko napotkają sprzyjające warunki, również w przyszłości będą inwestować i rozwijać się na miejscu. W tym sensie rozpatrywanie relacji między zagranicznymi inwestorami a firmami lokalnymi jako relacji specjalnych, traci częściowo na znaczeniu. Zarówno polityka gospodarcza, jak i działania samorządu gospodarczego nie powinny różnicować instrumentów adresowanych do tych dwóch kategorii firm.

prof. dr hab. Marian Gorynia, dr Matgorzata Bartosik-Purgat, dr Barbara Jankowska, dr Radostaw Owczarzak Katedra Handlu Międzynarodowego Akademia Ekonomiczna w Poznaniu

W artykule zaprezentowano wybrane wyniki uzyskane w ramach realizacji projektu badawczego Komitetu Badań Naukowych pt. Strategie firm polskich wobec ekspansji inwestorów zagranicznych (nr 2 H02D 011 24). Kierownikiem zespołu badawczego był prof. dr hab. Marian Gorynia. Członkami zespołu byli ponadto: dr Małgorzata Bartosik-Purgat, dr Barbara Jankowska, dr Radosław Owczarzak. Wszyscy są pracownikami Katedry Handlu Międzynarodowego na Wydziale Zarządzania Akademii Ekonomicznej w Poznaniu.

\section{PRZYPISY}

1) Por. M. GORYNIA, R. OWCZARZAK, Podstawy teorii internacjonalizacji $i$ globalizacji dziatalności przedsiębiorstw, „Gospodarka Narodowa” 2004, nr 1-2 oraz M. GORYNIA, B. JANKOWSKA, Konkurencja $w$ branży a internacjonalizacja $i$ globalizacja, „Gospodarka Narodowa" 2004, nr 11-12.

2) Szersze omówienie badania zawarto w: M. GORYNIA, M. BARTOSIK-PURGAT, B. JANKOWSKA, R. OWCZARZAK, Strategie firm polskich wobec ekspansji inwestorów zagranicznych - instrumenty polityki gospodarczej, „Przegląd Organizacji” 2005, nr 4.

3) Prezentacje próby badawczej zawarto w: ibidem.

4) Por. M. GORYNIA, Teoria i polityka regulacji mezosystemów gospodarczych a transformacja postsocjalistycznej gospodarki polskiej, Wydawnictwo Akademii Ekonomicznej w Poznaniu, Poznań 1995. 